\title{
ANALYSIS OF THE GAS INFRASTRUCTURE DEVELOPMENT
}

\begin{abstract}
In the article the analysis of gas infrastructure development has been presented made on the basis of data obtained from the Municipal Statistical Office during the network operation of gas system in the period 2006-2012. Also the results regarded gas infrastructure in provinces. An analysis of the gas lengths (up to $12306211 \mathrm{~km}$ ) and number of gas connections (an increase of 662815) indicates that the gas network is constantly expanded. The calculation of a gas network lenght falling to the unit of the surface area allowed to obtain a detailed picture of the operational situation of the operational gas network. The indicator of the equipping degree with gas networks show a growing trend in the considered period. The length of the gas network falling per unit - provided for the past 7 years ranges from 19.90 to $22.00 \mathrm{~km} / 100 \mathrm{~km}^{2}$ in villages and 34.10 to $37.60 \mathrm{~km} / 100 \mathrm{~km}^{2}$ in the cities. Also the situation with indicator describing number of gas connections falling per $1 \mathrm{~km}$ of gas network is similar, in villages ranges from 12.4 to $12.8 \mathrm{no} / \mathrm{km}$ and in cities 25.7 to $26.8 \mathrm{no} / \mathrm{km}$.
\end{abstract}

Słowa kluczowe: gas network, the gas infrastructure development indicators, gas consumption

\section{Introduction}

Nowadays gas as an energy source is widely used, what increases the amount of its use and lead to increase the network gas length. Development of heating, energy and industries based on natural gas was stimulated by introduction of environmental regulations. Natural gas is often described as a clean and environmentally friendly fuel. The gas from the controlled combustion does not emit dust, and gas emissions per unit of chemical energy of the fuel is less importance compared to solid and liquid fuels $[3,5]$. The use of conventional methods of energy production cause environment pollution, especially air pollution, land and water resource $[4,6,8]$. Thus, there is a tendency to choose

\footnotetext{
${ }^{1}$ Autor do korespondencji/corresponding author: Marek Urbanik, Politechnika Rzeszowska, al. Powstańców Warszawy 6, 35-959 Rzeszów, tel. 17 8651435, marekurbanik@ @p.pl

${ }^{2}$ Barbara Tchórzewska-Cieślak, Politechnika Rzeszowska, al. Powstańców Warszawy 6, 35-959 Rzeszów, tel. 17 8651435, cbarbara@prz.edu.pl
} 
such methods of energy supply, which allow the most efficient use of available resources [7, 9].

The aim of the work is the analysis of the gas infrastructure development in Poland in 2006-2012 years. Analysis concerned the following elements of the infrastructure: the length of gas network, the number of gas connections to residential and non-residential buildings, the numbers of gas connections falling per $1 \mathrm{~km}$ of the pipe, gas consumption for production and population purposes, indicator of the degree of equipping individuals settlement with gas systems, comparison of the gas infrastructure development in individual provinces. Basic source for writing this work was data from Municipal Statistical Office in years 1999-2013 [1, 2].

\section{Results of the gas infrastructure development analysis}

The increase of pipes length was presented in fig. 1 and in tab. 1. From 2006 a stable growth of pipes length is observed, both in cities, as well as in the country. Particularly the bigger increase of the network length was observed in the country (ca. 10\%). The greatest increase in the country appeared in 2007 and amounted $2744.23 \mathrm{~km}$ in comparison to 2006.

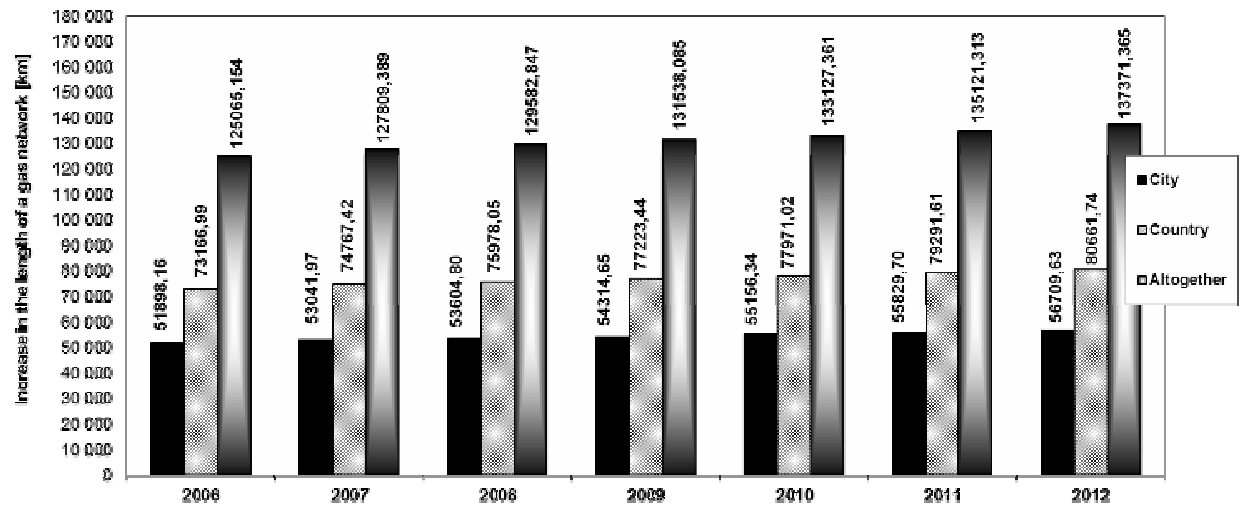

Fig. 1. Increase of the gas network length in the years 2006-2012, own research Rys. 1. Przyrost długości sieci gazowej w latach 2006-2012, opracowanie własne

Average increase of the gas length $\left(p_{a v}\right)$ in years 2006-2012 is possible to appoint on the basis of the relation:

$$
p_{a v}=\frac{l_{2006}-l_{2012}}{t}\left[\mathrm{~km} \cdot \text { year }^{-1}\right]
$$


Where $l_{2006}$ is the length of the gas network on the start of observation period (in 2006) in $\mathrm{km}, l_{2009}$ is the length of the gas network on the end of observation period (in 2009) in $\mathrm{km}, t$ is time of observation (7 years).

For the analysed period the average increase $p_{a v}$ is: for cities 687.35 $\mathrm{km} \cdot \mathrm{year}^{-1}$; for villages $1070.68 \mathrm{~km} \cdot \mathrm{year}^{-1}$; altogether $1758.03 \mathrm{~km} \cdot \mathrm{year}^{-1}$.

Table 1. Increase of the gas network length in the years 2006-2012, own research

Tabela 1. Przyrost długości sieci gazowej w latach 2006-2012, opracowanie własne

\begin{tabular}{|l|c|c|c|c|c|c|c|}
\hline \multirow{2}{*}{ Regional unit } & \multicolumn{7}{|c|}{ The gas network length [\%] } \\
\cline { 2 - 8 } & $\mathbf{2 0 0 6}$ & $\mathbf{2 0 0 7}$ & $\mathbf{2 0 0 8}$ & $\mathbf{2 0 0 9}$ & $\mathbf{2 0 1 0}$ & $\mathbf{2 0 1 1}$ & $\mathbf{2 0 1 2}$ \\
\hline Altogether & 100.00 & 102.19 & 103.61 & 105.18 & 106.45 & 108.04 & 109.84 \\
\hline Cities & 100.00 & 102.20 & 103.29 & 104.66 & 106.28 & 107.58 & 109.27 \\
\hline Villages & 100.00 & 102.19 & 103.84 & 105.54 & 106.57 & 108.37 & 110.24 \\
\hline
\end{tabular}

As a point of reference it was assumed that in 2006 the network length was $100 \%$.

The greatest average increase in the gas network length in individual provinces of Poland in years 2006-2012 took place in the wielkopolskie (tab. 2). In this province, in the seven-year-old period of observation the average increase of pipes length was altogether $264.7 \mathrm{~km}$, appropriately $190.36 \mathrm{~km}$ in the country and $74.39 \mathrm{~km}$ in the city (fig. 2). In remaining provinces the average increase

Table 2. Increase of the gas network length in the provinces in Poland in the years 2006-2012, own research

Tabela 2. Przyrost długości sieci gazowej w poszczególnych województwach Polski w latach 2006-2012, opracowanie własne

\begin{tabular}{|c|c|c|c|c|c|c|c|c|c|c|c|c|c|c|c|c|}
\hline \multirow{3}{*}{$\begin{array}{c}\text { Regio- } \\
\text { nal } \\
\text { unit }\end{array}$} & \multicolumn{16}{|c|}{ Provinces } \\
\hline & 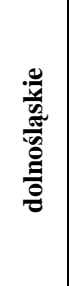 & 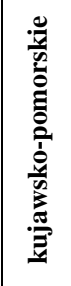 & 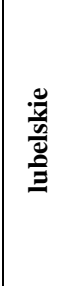 & 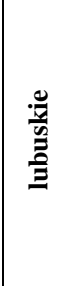 & 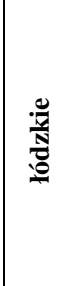 & 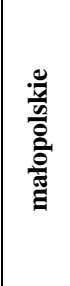 & 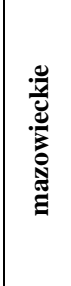 & $\frac{\frac{\pi}{\frac{\pi}{2}}}{\frac{0}{0}}$ & 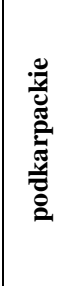 & 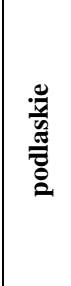 & 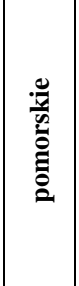 & $\frac{\frac{\mathscr{y}}{v}}{\frac{\pi}{\omega}}$ & 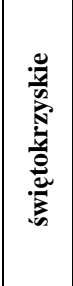 & 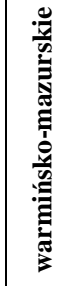 & 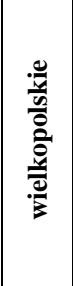 & 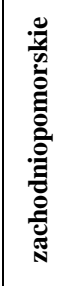 \\
\hline & [\%] & {$[\%]$} & [\%] & {$[\%]$} & [\%] & {$[\%]$} & [\%] & {$[\%]$} & {$[\%]$} & [\%] & {$[\%]$} & [\%] & {$[\%]$} & [\%] & {$[\%]$} & {$[\%]$} \\
\hline $\begin{array}{l}\text { Altoge- } \\
\text { ther }\end{array}$ & 108.53 & 119.95 & 110.04 & 116.42 & 119.03 & 103.43 & 113.54 & 114.34 & 103.47 & 108.27 & 135.62 & 105.35 & 108.93 & 111.98 & 115.71 & \\
\hline City & 105.81 & 110.55 & 111.48 & 108.16 & 114.77 & 107.49 & 112.24 & 109.58 & 115.52 & 108.90 & 119.40 & 105.37 & 111.06 & 91.25 & 110.78 & 106.93 \\
\hline Village & 112.51 & 137.54 & 109.46 & 123.91 & 128.02 & 102.20 & 114.70 & 122.30 & 100.77 & \begin{tabular}{|l|l}
107.58 \\
\end{tabular} & 167.77 & 105.31 & 107.96 & 147.36 & 119.13 & 115. \\
\hline
\end{tabular}

As a point of reference it was assumed that in 2006 the network length was $100 \%$. 
of the gas network length was in cities from $8.66 \mathrm{~km}$ to $109.70 \mathrm{~km}$ and in the country from $6.81 \mathrm{~km}$ up to $190.36 \mathrm{~km}$. The greatest increase of the gas network length towards 2006 occurred in provinces: Pomorskie (height of about $135.62 \%$ ), Kujawsko-Pomorskie (height of about 119.95\%) and Łódzkie (height of about $119.03 \%$ ), however the smallest increase in the gas network was observed in provinces: Podkarpackie, Małopolskie and Śląskie (appropriately $103.47 \%, 103.43 \%$ and $105.35 \%$ ) (tab. 2).

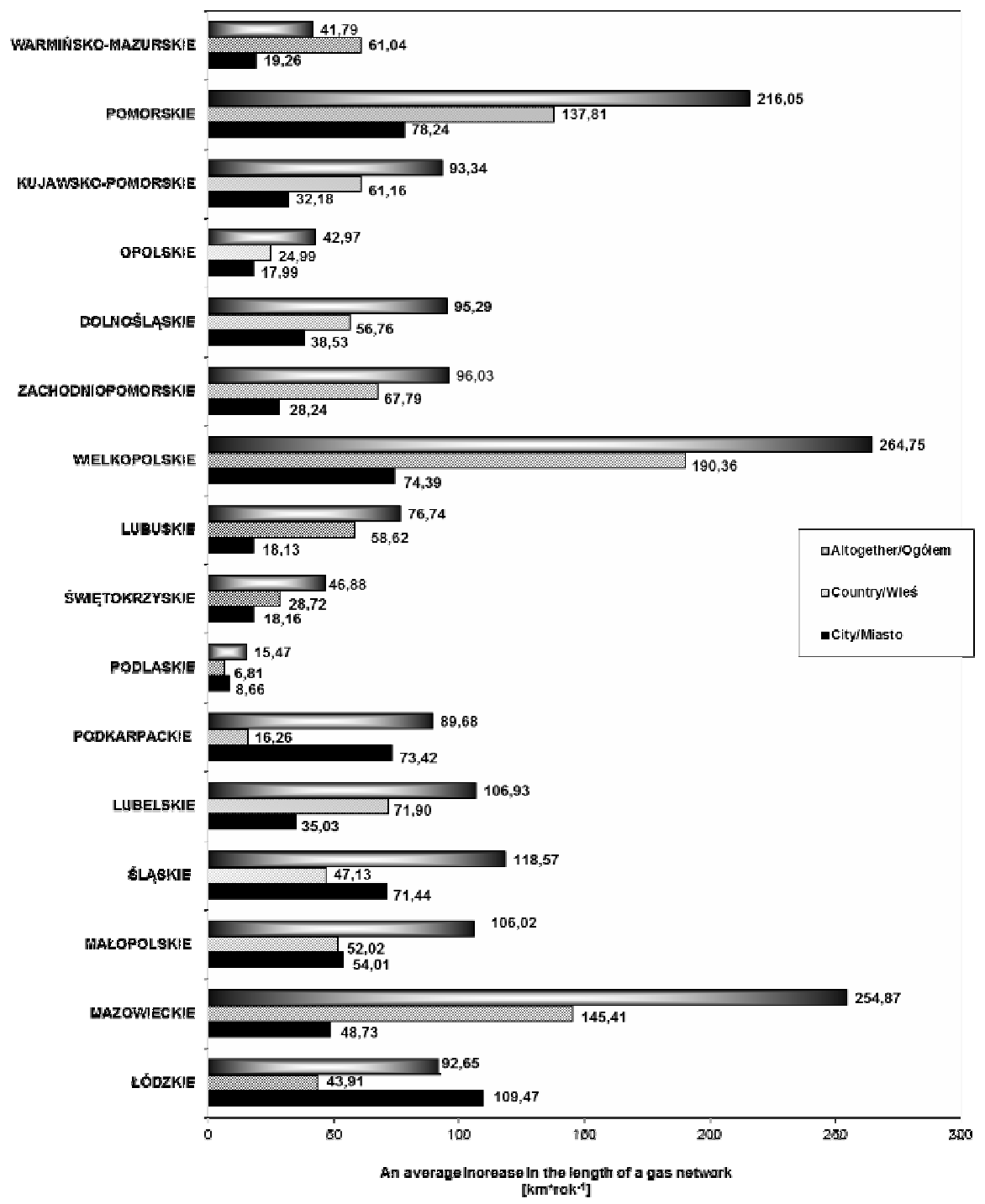

Fig. 2. An average increase of the gas network length in the years 2006-2012, own research Rys. 2. Średni przyrost długości sieci gazowej w latach 2006-2012, opracowanie własne 
Along with the increase of the gas network length the number of gas connections in the considerable period increased in case of the village to $34.39 \%$, and in the cities to $35.53 \%$ (fig. 3 and tab. 3 ).

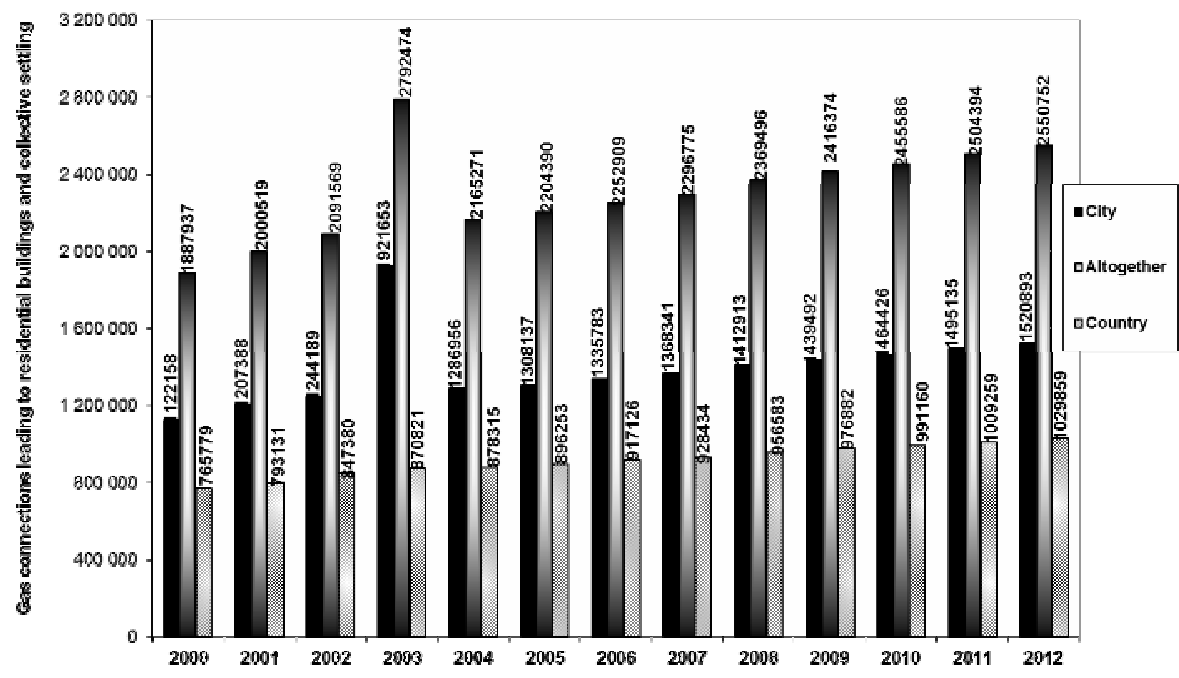

Fig. 3. Gas connections leading to residential buildings and collective settling in the years 2000-2012, own research

Rys. 3. Przyłącza gazowe prowadzące do budynków mieszkalnych i zbiorowego zamieszkania w latach 2000-2012, opracowanie własne

Table 3. Gas connections leading to residential buildings and collective settling in the years 2000-2012, own research

Tabela 3. Przyłącza gazowe prowadzące do budynków mieszkalnych i zbiorowego zamieszkania w latach 2000-2012, opracowanie własne

\begin{tabular}{|l|c|c|c|c|c|c|c|c|c|c|c|c|c|}
\hline $\begin{array}{c}\text { Regio- } \\
\text { nal } \\
\text { unit }\end{array}$ & \multicolumn{6}{|c|}{ Gas connections leading to residential buildings and collective settling [\%] } \\
\cline { 2 - 13 } & $\mathbf{2 0 0 0}$ & $\mathbf{2 0 0 1}$ & $\mathbf{2 0 0 2}$ & $\mathbf{2 0 0 3}$ & $\mathbf{2 0 0 4}$ & $\mathbf{2 0 0 5}$ & $\mathbf{2 0 0 6}$ & $\mathbf{2 0 0 7}$ & $\mathbf{2 0 0 8}$ & $\mathbf{2 0 0 9}$ & $\mathbf{2 0 1 0}$ & $\mathbf{2 0 1 1}$ & $\mathbf{2 0 1 2}$ \\
\hline $\begin{array}{l}\text { Altoge- } \\
\text { ther }\end{array}$ & 100.00 & 105.96 & 110.79 & 147.91 & 114.69 & 116.76 & 119.33 & 121.66 & 125.51 & 127.99 & 130.07 & 132.65 & 135.11 \\
\hline City & 100.00 & 107.60 & 110.87 & 171.25 & 114.69 & 116.57 & 119.04 & 121.94 & 125.91 & 128.28 & 130.50 & 133.24 & 135.53 \\
\hline Village & 100.00 & 103.57 & 110.66 & 113.72 & 114.70 & 117.04 & 119.76 & 121.24 & 124.92 & 127.57 & 129.43 & 131.80 & 134.49 \\
\hline
\end{tabular}

As a point of reference it was assumed that in 2000 the sum of gas connections leading to residential buildings and collective settling was $100 \%$. 
Knowing the length of distribution pipes, it is possible to establish the number gas connections falling per $1 \mathrm{~km}$ of the gas pipes $-l_{a v}$ from the relation:

$$
l_{a v}=\frac{n}{\sum l_{r}}\left[\mathrm{no}^{\mathrm{km}}{ }^{-1}\right]
$$

where $n$ is the number of gas connections, $\sum l_{r}-$ the length of gas pipes [km].

For the analysed period the average increase $l_{s r}$ is: for cities $26 \mathrm{no} \cdot \mathrm{km}^{-1}$; for villages $12 \mathrm{no} \cdot \mathrm{km}^{-1}$; altogether $18 \mathrm{no} \cdot \mathrm{km}^{-1}$. The number of gas connections is strictly associated with the density of the building development, therefore the number of gas connections in cities is bigger in comparison with the village, on average of about $18 \mathrm{no} \cdot \mathrm{km}^{-1}$ (fig. 4).

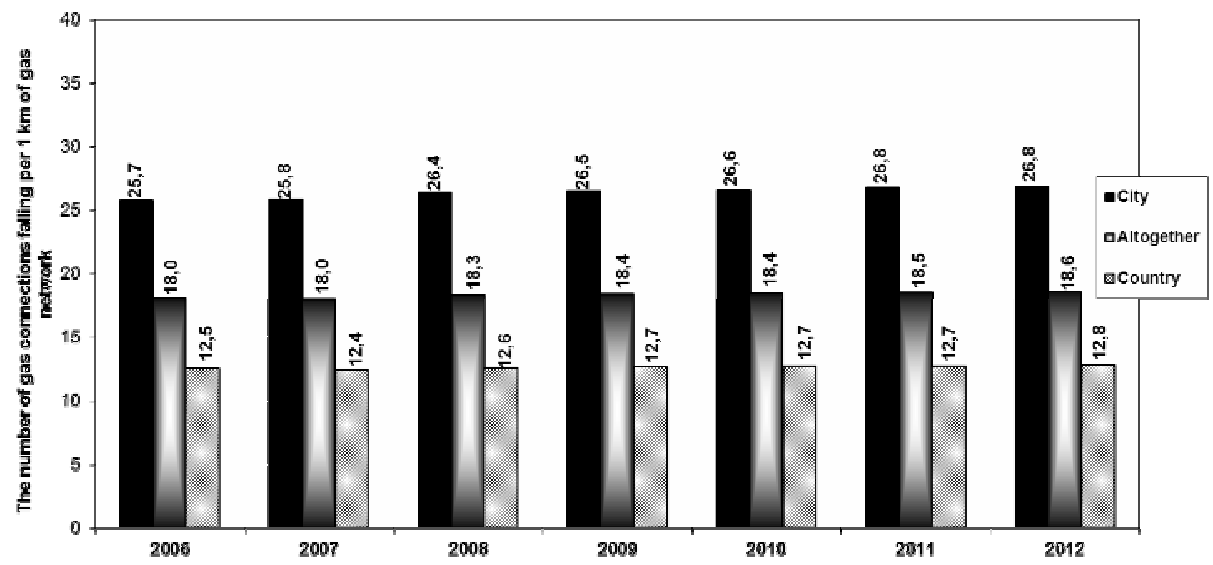

Fig. 4. The number of gas connections falling per $1 \mathrm{~km}$ of gas network, own research

Rys. 4. Liczba przyłączy gazowych przypadających na $1 \mathrm{~km}$ przewodów gazowych, opracowanie własne

The gas consumption for the industry and building purpose amounted on average in distinguished period of time $1627989.3 \mathrm{dam}^{3}$, what constituted the $69.30 \%$ of total gas charged (fig. 5). From 2006 in gas consumption for heating houses is observed stable gas consumption, the maximum consumption $\left(2836434.2 \mathrm{dam}^{3}\right)$ was recorded in 2010 and the smallest gas consumption in 2007, it amounted $2370280.2 \mathrm{dam}^{3}$. Also gas consumption for commerce and services is on the same level and amounted on average $11.56 \%$.

A good indicator describing equipping with gas systems is number of households connected to the gas network what was presented in tab. 4. In 2012 the number of households using gas for villages amounted $117.73 \%$ and for cities it remained on the same level. 


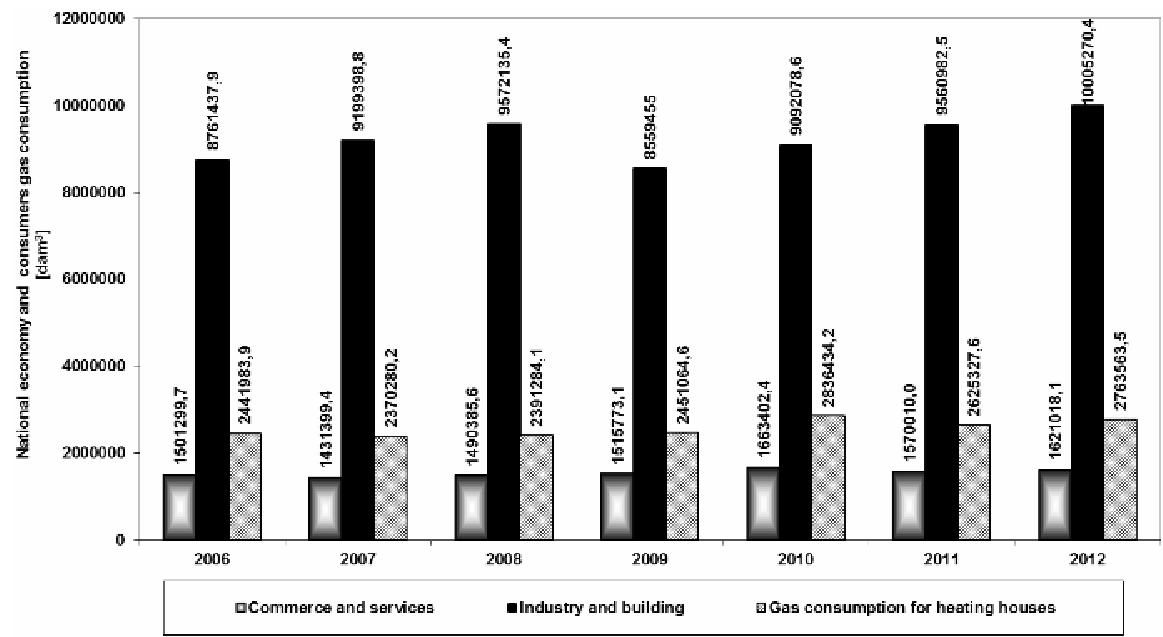

Fig. 5. National economy and consumers gas consumption in the years 2006-2012, own research

Rys. 5. Zużycie wody na potrzeby gospodarki narodowej i ludności w województwie podkarpackim w latach 2006-2012, opracowanie własne

Table 4. Number of households connected to the gas network gas network in the years 2006-2012, own research

Tabela 4. Gospodarstwa domowe przyłączone do sieci gazowej w latach 2006-2012, opracowanie własne

\begin{tabular}{|l|c|c|c|c|c|c|c|}
\hline \multirow{2}{*}{ Regional unit } & \multicolumn{6}{|c|}{ Number of households connected to the gas network [\%] } \\
\cline { 2 - 8 } & $\mathbf{2 0 0 6}$ & $\mathbf{2 0 0 7}$ & $\mathbf{2 0 0 8}$ & $\mathbf{2 0 0 9}$ & $\mathbf{2 0 1 0}$ & $\mathbf{2 0 1 1}$ & $\mathbf{2 0 1 2}$ \\
\hline Altogether & 100,00 & 100,35 & 101,21 & 101,61 & 101,89 & 102,30 & 102,83 \\
\hline Cities & 100,00 & 99,90 & 100,50 & 100,67 & 100,71 & 100,76 & 100,96 \\
\hline Villages & 100,00 & 103,93 & 106,88 & 109,11 & 111,24 & 114,57 & 117,73 \\
\hline
\end{tabular}

As a point of reference it was assumed that in 2006 the number of households connected to the gas network was $100 \%$.

One of the indicators describing the development of gas infrastructure is the equipping degree indicator with gas networks. This indicator describes what length of gas network is falling per unit area [1]. These indicators are calculated on the basis of data collected by the Statistical Municipal Office. On figure 6 this indicator is presented for 2006-2012 years. It results from presented data that the length of gas network falling per unit area in city is bigger compared with the village. This situation is caused by the fact that in cities more residents are falling per unit area. 


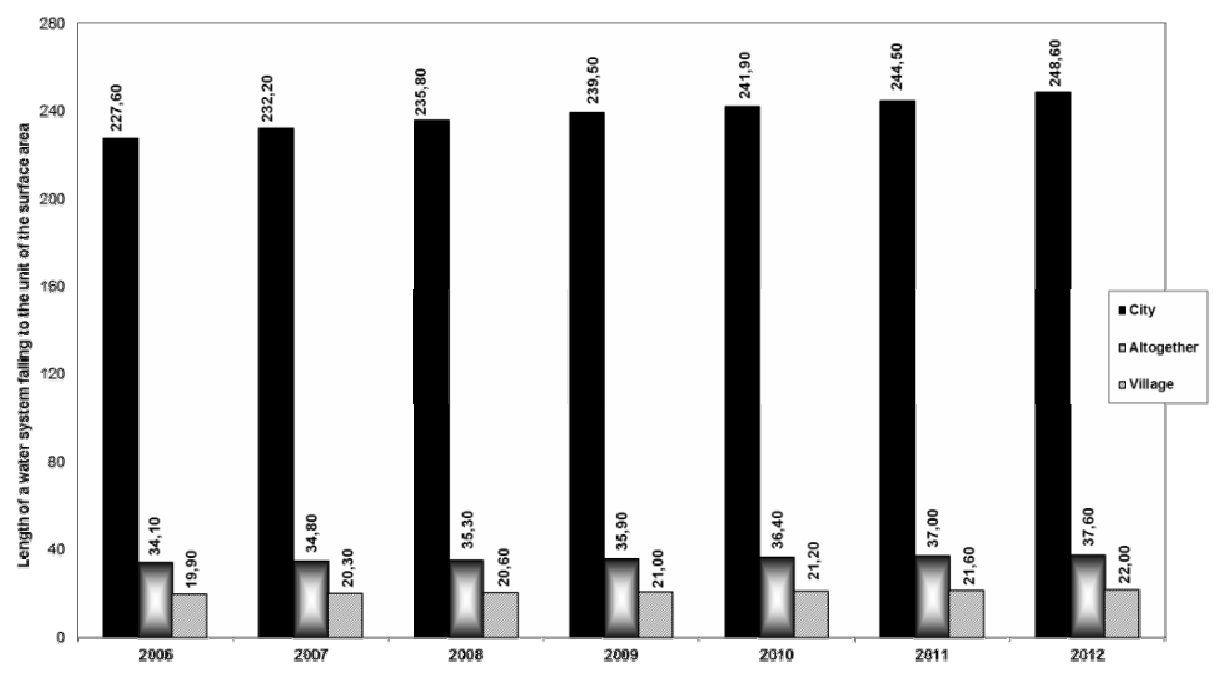

Fig. 6. Gas network length falling to the unit of the surface area in the years 2006-2012, own research

Rys. 6. Długość sieci gazowej przypadającej na jednostkę powierzchni w latach 2006-2012, opracowanie własne

In the provincial arrangement the biggest rate of the network density is in provinces: małopolskie (altogether $137.7 \mathrm{~km} / 100 \mathrm{~km}^{2}$ ), śląsie (altogether 120.1 $\mathrm{km} / 100 \mathrm{~km}^{2}$ ) and podkarpackie (altogether $94.4 \mathrm{~km} / 100 \mathrm{~km}^{2}$ ). In other provinces the smallest value is in the villages and in the provinces: podlaskie (altogether $1.5 \mathrm{~km} / 100 \mathrm{~km}^{2}$ ), warmińsko-mazurskie (altogether $2.3 \mathrm{~km} / 100 \mathrm{~km}^{2}$ ) and opolskie (altogether $3.3 \mathrm{~km} / 100 \mathrm{~km}^{2}$ ). The biggest length of the gas network falling per unit area in the cities appears in the wielkopolskie (altogether 343 $\mathrm{km} / 100 \mathrm{~km}^{2}$ ), mazowieckie (altogether $318.9 \mathrm{~km} / 100 \mathrm{~km}^{2}$ ) and małopolskie (altogether $307.1 \mathrm{~km} / 100 \mathrm{~km}^{2}$ ).

\section{Conclusion}

From 2006 a stable development of the gas infrastructure took place, both in cities and in the country. This development was characterized by an increase: the gas system length from $125065.15 \mathrm{~km}$ in 2006 to $137371.37 \mathrm{~km}$ in 2012 what constitutes the height of $9.84 \%$, gas connection from 1887937 in 2006 to 9.84 in 2012 what constitutes the height of $35.11 \%$. Along with the development of the gas system infrastructure it is difficult to distinguish growing or descending trend in gas consumption, it remains on the same level. The main cause of stability of gas consumption in the analysed period is the growing of the gas price. 


\section{References}

[1] Główny Urząd Statystyczny. Infrastruktura komunalna w 2009 r., www.stat.gov.pl.

[2] Główny Urząd Statystyczny. Ochrona środowiska. Roczniki statystyczne 1999-2008.

[3] Gorczyca M.: Stan rozwoju gazownictwa - statystyczne spektrum. Gaz, Woda i Technika Sanitarna, nr 5, 2010, s. 2-5.

[4] Kaliski M., Staśko D.: Bezpieczeństwo energetyczne w gospodarce paliwowej Polski. Instytut Gospodarki Surowcami Mineralnymi i Energią Polskiej Akademii Nauk, Kraków 2006.

[5] Kaliski M., Janusz P., Szurlej A.: Wpływ infrastruktury przesyłowej gazu ziemnego na wielkość jego zużycia w Polsce. Prace Naukowe Instytutu Nafty i Gazu, nr 173, 2010, s. 9-18.

[6] Krakowiak-Bal A.: Infrastruktura techniczna wiejskich gmin górskich w aspekcie ich wielofunkcyjnego rozwoju. Infrastruktura i Ekologia Terenów Wiejskich, seria: rozprawy 3, Kraków 2004.

[7] Podziemski T., Bałut H.: W XXI wieku gaz ziemny źródłem prądu, ciepła i chłodu. Gaz, Woda i Technika Sanitarna, nr 2, 2003, s. 57-63.

[8] Siemek J., Nagy S., Siemek P.: Challenges for sustainable development: The case of shale gas exploitation in Poland. Problemy Ekorozwoju: Studia Filozoficzno-Sozologiczne, nr 1, 2013, s. 91-104.

[9] Steczko K., Rachwalski J.: Zalety gazu ziemnego jako paliwa. Gaz, Woda i Technika Sanitarna, nr 4, 2000, s. 145-150.

\section{ANALIZA ROZWOJU INFRASTRUKTURY GAZOWEJ}

Streszczenie

W pracy przedstawiono analizę rozwoju infrastruktury gazowej przeprowadzoną na podstawie danych uzyskanych z Głównego Urzędu Statystycznego podczas eksploatacji sieci gazowej w latach 2006-2012. Uzyskane wyniki odniesiono do systemów zaopatrzenia w gaz znajdujących się w poszczególnych województwach. Analiza długości gazu (wzrost do $12306211 \mathrm{~km}$ ) i liczby połączeń gazowych (wzrost o 662.815) wskazuje, że sieć gazowa jest ciagle rozbudowywana. Wyznaczenie wskaźnika opisującego długość sieci gazowej przypadającej na jednostkę powierzchni pozwoliło na uzyskanie szczegółowego obrazu sytuacji eksploatacyjnej gazociagu. W badanym okresie wskaźniki stopnia wyposażenia w sieci gazowe wykazały tendencję wzrostową. Długość sieci gazowej przypadającej na jednostkę powierzchni w ciagu ostatnich 7 lat wynosila od 19,90 do $22,00 \mathrm{~km} / 100 \mathrm{~km}^{2}$ na wsi oraz od 34,10 do $37,60 \mathrm{~km} / 100 \mathrm{~km}^{2}$ w miastach. Podobna sytuacja występuje w przypadku wskaźnika opisującego liczbę przyłączy gazowych przypadających na $1 \mathrm{~km}$ sieci gazowej - od 12,4 do 12,8 szt./km (wieś) oraz w miastach od 25,7 do $26,8 \mathrm{szt} . / \mathrm{km}$.

Słowa kluczowe: sieć gazowa, wskaźniki rozwoju infrastruktury gazowej, zużycie gazu

Przestano do redakcji: 20.04 .2014 r.

Przyjęto do druku: 02.12.2014 r.

DOI: $10.7862 /$ rb.2014.143 
